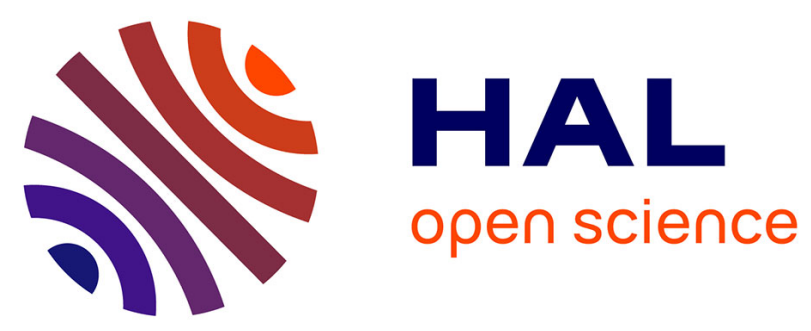

\title{
Chronic use of proton pump inhibitors, adverse events and potential biological mechanisms: A translational analysis
}

Farid Kheloufi, Diane Frankel, Elise Kaspi, Marion Lepelley, Michel Mallaret, Quentin Boucherie, Patrice Roll, Joëlle Micallef

\section{To cite this version:}

Farid Kheloufi, Diane Frankel, Elise Kaspi, Marion Lepelley, Michel Mallaret, et al.. Chronic use of proton pump inhibitors, adverse events and potential biological mechanisms: A translational analysis. Thérapie, 2018, 10.1016/j.therap.2017.08.003 . hal-01664284

\section{HAL Id: hal-01664284 \\ https://hal-amu.archives-ouvertes.fr/hal-01664284}

Submitted on 29 Mar 2018

HAL is a multi-disciplinary open access archive for the deposit and dissemination of scientific research documents, whether they are published or not. The documents may come from teaching and research institutions in France or abroad, or from public or private research centers.
L'archive ouverte pluridisciplinaire HAL, est destinée au dépôt et à la diffusion de documents scientifiques de niveau recherche, publiés ou non, émanant des établissements d'enseignement et de recherche français ou étrangers, des laboratoires publics ou privés. 
Full Title : Chronic Use of proton pump inhibitors, adverse events and potential biological mechanisms: a translational analysis

Short Title : Proton pump inhibitors and pharmacosurveillance

Kheloufi $\mathrm{F}^{1,2}$, Frankel $\mathrm{D}^{3,4}$, Kaspi $\mathrm{E}^{3,4}$, Lepelley $\mathrm{M}^{5}$, Mallaret $\mathrm{M}^{5}$, Boucherie $\mathrm{Q}^{1,2}$, Roll $\mathrm{P}^{3,4}$, Micallef $\mathbf{J}^{1,2}$

${ }^{1}$ Regional Pharmacovigilance Centre of Marseille Provence Corse, Department of Clinical Pharmacology and Pharmacovigilance, Assistance Publique - Hôpitaux de Marseille, Marseille, France

${ }^{2}$ Aix Marseille Université, Institut de Neurosciences Timone, CNRS 7289

${ }^{3}$ INSERM, GMGF UMRS 910, Aix-Marseille University, Marseille, France

${ }^{4}$ Hôpital la Timone, Service de Biologie Cellulaire, Marseille, France

${ }^{5}$ Regional Pharmacovigilance Centre of Grenoble, CHU de Grenoble, France

*Corresponding author:

Joelle MICALLEF, M.D., Ph.D.

Regional Pharmacovigilance Centre of Marseille Provence Corse

270 boulevard Sainte Marguerite

13009 MARSEILLE

Email: joelle.micallef@ap-hm.fr

Telephone: +33491747560

\section{Conflict of interest}

Farid KHELOUFI has no conflicts of interest to disclose. Diane FRANKEL has no conflicts of interest to disclose. Elise KASPI has no conflicts of interest to disclose Marion LEPELLEY has no conflicts of interest to disclose Michel MALLARET has no conflicts of interest to disclose Quentin BOUCHERIE has no conflicts of interest to disclose Patrice ROLL has no conflicts of interest to disclose Joëlle MICALLEF has no conflicts of interest to disclose 


\section{Resume}

Les inhibiteurs de la pompe à protons (IPP) sont parmi les médicaments les plus prescrits. Des effets indésirables sont rapportés lors d'une utilisation chronique, souvent en dehors des indications appropriées. L'objectif de ce travail est, après une synthèse précise des études de pharmacoépidémiologiques positives sur le risque de complications rénales, cardiovasculaires et neurologiques (démence, insuffisance rénale chronique, infarctus du myocarde et accident vasculaire cérébral), de proposer une analyse globale et intégrée des mécanismes biologiques potentiellement impliqués.

Onze études pharmacoépidémiologiques, principalement menées sur des bases de données de d'assurance maladie et d'hospitalisation, ont montré un risque accru de complications associées à l'utilisation du PPI, et souvent lors d'une dose cumulée évocatrice d'une possible relation dose-effet. Plusieurs mécanismes ont été suggérés par des études in vitro (dysfonction endothéliale, sénescence endothéliale, hypomagnésémie, augmentation des taux de chromogranine $\mathrm{A}$, diminution du $\mathrm{NO}$ dans les cellules endothéliales) conduisant à une altération de l'homéostasie vasculaire, pouvant favoriser la survenue de ces complications. Les données disponibles suggèrent que les IPP pourraient avoir un effet Off target, nécessitant une attitude prudente dans leur prescription, en particulier chez les personnes âgées et / ou dans le contexte d'une utilisation chronique. 


\begin{abstract}
Proton pump inhibitors (PPIs) are among the most frequently prescribed drugs. Even if PPI are usually considered as safe, there is a growing concern for a range of adverse effects of chronic PPI therapy often in the absence of appropriate indications. We propose, after a summary of renal, cardiovascular and neurological complications (dementia, chronic kidney disease, myocardial infarction and stroke), an integrative overview of the potential biological mechanisms involved.

Eleven positive pharmacoepidemiological studies, mainly based on Health Insurance Database linkage to hospital database, reported an increased risk of complications associated to PPI use and often a graded association suggesting also a possible dose-response relationship. Several mechanisms have been suggested through in vitro studies (endothelial dysfunction, endothelial senescence, hypomagnesemia, increase of chromogranin A levels, decrease of NO in endothelial cells) leading to the impairment of vascular homesostasis, paving the way to these complications.

Evidence that PPIs may have off-targets and pleiotropic effects are mounting and may impose a cautious attitude in the prescription of PPI's, especially in elderly and/or in the context of chronic use.
\end{abstract}

Keys words : Proton Pump Inhibitors - Safety - Endothelial dysfunction - Vascular risk Pharmacoepidemiology- Pharmacovigilance

Mots clés : Inhibiteurs de la pompe à protons - Sécurité - Dysfonctionnement endothelial risque vasculaire - Pharmacoépidémiologie - Pharmacovigilance 


\section{Abréviations}

ADMA : asymmetrical dimethylarginine

ARIC : Atherosclerosis Risk in Communities

CANTAB : CAmbridge Neuropsychological Test Automated Battery

CgA : Chromogranin-A

CKD : Chronic Kidney Disease

DDAH : dimethylarginine dimethylaminohydrolase

DMSO : dimethyl sulphoxide

eGFR : estimated Glomerular Filtration Rate

GHS: Geisinger Health System

NO: nitric oxide

NOS: nitric oxide synthase

PPIs : Proton pump inhibitors

PS: Propensity Score 


\section{Introduction}

Proton pump inhibitors (PPIs) are among the most frequently prescribed drugs. In 2012, this class ranked in the top 10 national health-related drug expenditures in United States [1]. The proportion of PPI use is also high in some European countries. In Spain, omeprazole ranked number one in drug sales in 2010, representing 5.5\% of total drug packaging invoiced [2]. The use of antiulcer agents in Spain has increased almost four times since the year 2000, primarily due to an increase in PPI use [2]. Similar trends are seen in other countries including the Netherlands, Iceland, Denmark, United Kingdom, Belgium, France and Australia [2-5]. Health care providers are increasingly prescribing PPIs for prolonged, sometimes lifetime, use, often without appropriate indications [6]. Furthermore, in several countries several PPIs are available over-the-counter, which encourages their consumption especially for unapproved indications [7]. Many studies have been published on the rate of inappropriateness of PPI in both hospitalized and primary care patients, ranging from $27 \%$ to $81 \%[8-9]$.

Even if PPI are usually considered as safe, there is a growing concern for a range of potential adverse effects due to chronic PPI therapy $[6,10]$. More precisely, recent evidence suggests that long term use of PPIs may increase the risk of dementia [11-12] chronic kidney diseases [13-14] and cardiovascular events such as strokes or myocardial infarctions [15-16]. Because new data on biological and clinical experiments with PPI have been published during the same period, we propose, after a summary of these complications, an integrative overview of the potential biological mechanisms involved. 


\section{Drug safety issues related to PPIs are increasing}

Many pharmacoepidemiological studies described potential adverse effects of PPI long-term use (Table 1). Over the past 3 years, safety issues related to neurological disorders have also been described, concerning the potential involvement of PPI as a putative factor of dementia, especially in elderly people. The first study published in 2015 was performed on data from a longitudinal multicenter cohort study in elderly primary care patients, the German Study Aging, Cognition and Dementia in primary care (AgeCoDe) including 3327 communitydwelling persons aged $>75$ years [17]. The use of PPI had a significantly increased risk of any dementia $(\mathrm{HR}=1.38)$ and Alzheimer disease $(\mathrm{HR}=1.44)$. Of the covariates included in the study, the known risk factors, age, the presence of ApoE4 allele, depression, diabetes, and stroke were found to increase significantly the risk of any dementia and/or Alzheimer disease [17].

The study of Gomm et al. was performed on a longitudinal sample of patients free of dementia, aged of 75 years $(n=73$ 679) from the largest German Insurance health database including inpatient and outpatient diagnosis (ICD codes) and drugs prescriptions [11].

Using Cox regression with time-dependent variables, and after adjustment for potential confounding factors (age, sex, comorbidity and polypharmacy), a significantly increased risk of incident dementia was found in patients receiving regular PPI compared with the patients without PPI medication $(\mathrm{HR}=1.44)$. As expected, anticholinergic drug use was also a risk factor of incident dementia $(\mathrm{HR}=1.80)$.

More recently, a study performed on a population-based cohort (7 863 PPI users) identified from Taiwan's national Health Insurance research Database confirmed the previous works of the two German studies [12]. After propensity score matching and adjustment for the 
covariates, PPI users had a slightly risk of developing dementia than non-users $(H R=1.22)$. A significant association between cumulative PPI use and all-cause dementia (trend $p$-value $=$ 0.013) was also found.

Recently two clinical pharmacology studies have shown a significant association between IPP and impairment on cognitive function [18-19]. Akter et al. investigated the effects of a shortterm exposure of several PPIs on cognitive functions using a computerized neuropsychological tests battery (Cambridge Neuropsychological Test Automated Battery) called CANTAB which is well documented and validated to measure cognitive impairment in patients and healthy subjects [20]. Sixty healthy and young subjects (range 20-26 years) of either gender were randomly assigned into 6 groups (five groups according each IPP and one placebo group) [18]. A statistically and clinically significant impairment in visual memory, attention, executive function working and planning function was found. Interestingly, using a very large UK population cohort ( $\mathrm{n}=502647$ participants) assessed by three validated cognitive tests (verbal-numerical reasoning, memory and reaction time), participants in their middle age taking PPIs showed poorer cognitive function compared to non-takers [19].

Recent studies reported that the use of PPIs was also associated with kidney function impairment, and more particularly with chronic kidney disease (CKD).

Xie et al. 2016 have performed a retrospective observational study in the Department of Veterans Affairs national databases, including new users of PPIs ( $\mathrm{n}=173$ 321) and new users of H2-receptor antagonists ( $\mathrm{n}=20270)$ [21]. The authors reported an increased relative risk of incident CKD associated with PPIs use compared with $\mathrm{H} 2$ receptor antagonist use $(\mathrm{HR}=1.22)$ They also reported increased relative risks of other endpoints related to renal function, including eGFR (estimated Glomerular Filtration Rate) decline of $>30 \%(\mathrm{HR}=1.32)$ and end stage renal disease $(\mathrm{HR}=1.96)$. 
Lazarus et al. conducted a prospective observational study $(n=10482)$ in the Atherosclerosis

Risk in Communities (ARIC) study between 1996 and 2011 and a retrospective study ( $\mathrm{n}=248$ 751) in the Geisinger Health System (GHS), a large rural health care system in the US. The authors reported an increased risk of CKD (as ascertained by ICD codes determined through linkage to the United States Renal Data System registry) associated with self-report PPIs use in the ARIC cohort $(\mathrm{HRa}=1.50)[14]$. They have replicated these findings in the Geisinger Health System cohort $(\mathrm{HRa}=1.17)$ with the diagnosis of CKD based on eGRF and use of PPI by prescription claims. A higher risk was observed in patients prescribed twice daily at baseline $(\mathrm{HRa}=1.46)$ suggesting a dose-response relationship. The authors estimated an absolute difference in 10-year CKD risk of $1.7 \%$ to $3.3 \%$ attributable to PPI use, translating into a number needed to harm of approximately from 30 to 60 . Sensitivity analysis including a time-varying exposure model, propensity-score matching strengthened the findings [14]. Arora et al compared PPI users versus non-users from the Veterans Affairs Health Care New York and observed a higher risk of CKD (incident $<60 \mathrm{ml} / \mathrm{mi} / 1.73 \mathrm{~m} 2$ ) in PPIs users [13]. Xi et al aimed to assess the association of PPI use and the risk of long-term outcomes (including incident $\mathrm{CKD}, \mathrm{CKD}$ progression and end stage renal disease) in those without intervening acute kidney injury (AKI), endorsing the possibility of a direct effect of PPI on chronic renal outcomes [22]. Lastly Klatte et al assessed the association between PPI use and the risk of CKD progression [23].Using the Stockholm CREatinine Measurements database from 2006 to 2011, a cohort of new users of PPIs ( $n=105$ 305) and new users of H2 blockers ( $n=9578)$ was identified. The primary outcome was the progression of CKD (defined as doubling of creatinine or decrease of eGFR of $30 \%$ or more). The secondary outcomes were end-stage renal disease and AKI. Users of PPIs had an increased risk for doubled levels of creatinine $(\mathrm{HRa}=1,26)$ and a decrease in eGFR $(\mathrm{HRa}=1.26)$. An increasing cumulative PPI use was associated with a higher risk for both primary outcome [23]. 
Cardiovascular events have also been associated with PPIs. The association between PPI use

and cardiovascular events has been extensively studied due to a possible pharmacokinetic interaction with antiplatelet therapy [24-28]. Recently several pharmacoepidemiological studies have been performed to address the effect of PPI alone [15, 29-30]. A populationbased study from Ontario between 1996 and 2008 using a self-matched case series found that the initiation of PPIs was associated with a higher risk of acute myocardial infarction (OR $=1,8)$ and heart failure $(\mathrm{OR}=1.8)$ [29]. Similar findings were also described with histamine $\mathrm{H} 2$ receptor antagonists and benzodiazepines, with no known cardiac toxicity, restricting the added value of this work. Shi et al conducted a nationwide population-based study using the Taiwan National Health Insurance Research Database [30]. Two different study designs were performed to identify the association between PPI use and MI, the first using a propensity score-matching analysis (PS) and the second a case-crossover analysis. In the PS study, PPI use was associated with a 1.58 -fold greater risk of MI. The association remains consistent across subgroups defined by age, gender and diabetes mellitus. In the second approach, PPI use was still associated with an increased risk for MI for 7-day and 14-day window period.

Using a complex approach for mining clinical data (clinical notes both inpatient and outpatient) for pharmacovigilance, Shah et al. demonstrated a two-fold increase of cardiovascular mortality in patients with gastroesophageal reflux disease exposed to PPI (HR $=2.00 ; 95 \%$ CI 1.07-3.78; $\mathrm{P}=0.031)$ [15]. No cardiovascular risk was found with histamine H2-receptor antagonist (Shah, 2015). A retrospective nationwide study on Taiwan national health insurance was performed to assess the risk of first-time ischemic stroke associated with PPI use [16]. Two analyses were applied, one using a propensity score analysis (PS) and the second using a nested case-control design. In the PS study, PPI use was associated with a 
1.36-fold greater risk of stroke. In the second approach, PPI use was still associated with an increased risk for stroke for 30 days, between 31 to 90 days and between 91 and 180 days.

\section{Potential biological mechanisms are emerging}

Recently, many pathophysiological hypotheses have been proposed to explain cardiovascular events, renal failure and neurological defects potentially induced by PPIs. The biological pathways we present here are inter-connected and linked with 3 major mechanisms which could conduct to high vascular risk, nephrotoxicity and dementia: i) increase of endothelial senescence, ii) endothelial dysfunction and iii) lysosomal acidification impairment (Figure 1). Yepuri et al. demonstrated using human endothelial cells, that a chronic exposure of esomeprazole, but not of another $\mathrm{H}+/ \mathrm{K}+$ ATPase inhibitor called $\mathrm{SCH}-28080$, led to an endothelial senescence linked to telomere attrition and oxidative stress [31]. This accelerated endothelial aging was associated with a reduced endothelial cell proliferation and angiogenesis. To support the senescence hypothesis, Costarelli et al. showed by using a transcriptomic approach on human coronary artery endothelial cells, that treatment by omeprazole or lansoprazole induced a down-regulation of genes encoding anti-atherogenic chemokines in senescent endothelial cells, while these genes were up-regulated in untreated senescent cells [32]. By this way, PPIs could activate pro-atherogenic pathways in endothelial senescent cells.

Endothelial dysfunction is defined as a reduction in vasodilation in response to endothelial stimuli leading to the development of pathological inflammatory processes and vascular disease. Reduced nitric oxide (NO) synthesis and release by endothelial cells is one of the major mechanism associated with endothelial dysfunction [33]. Using biochemical in vitro, ex vivo and in vivo experiments, Ghebremariam et al. demonstrated that PPIs significantly inhibited human dimethylarginine dimethylaminohydrolase (DDAH) activity [34]. This led to 
an increase of endothelial and serum asymmetrical dimethylarginine (ADMA) levels endothelial cells. Yepuri et al. also demonstrated a decrease of DDAH1/2 expression in endothelial cells associated with a decrease of endothelial NOS (eNOS), inducible NOS (iNOS) and NO generation [31]. The increase in ADMA levels may lead to a disruption of vascular homeostasis via a decrease of $\mathrm{NO}$ release, which could explain the increase risk of adverse vascular events in patients receiving PPIs.

Furthermore, the European Medicine Agency recently provided a special warning on the increase of circulating level of Chromogranin-A (CgA) in patients under PPIs [35-36]. $\mathrm{CgA}$ is a soluble protein secreted from the adreno-medullary chromaffin granules. The proteolytic processing of $\mathrm{CgA}$ generates fragments (e.g catestatin, pancreastatin, vasostatin and serpinin) [37]. $\mathrm{CgA}$ and its fragments generate different angiogenic effects: $\mathrm{CgA}$ and vasostatin-1 exert anti-angiogenic effects CgA by inhibiting the TNF-elicited changes on endothelial cells and the proangiogenic Vascular Endothelial Growth Factor) [38], whereas catestatin activates endothelial angiogenesis, vascularization, proliferation, cell chemotaxis and inhibits endothelial cell apoptosis [39]. An elevated plasma level of $\mathrm{CgA}$ has also been described in several cardiovascular pathological contexts as essential hypertension, hypertension secondary to parenchymal disease and chronic heart failure. Moreover, Chen et al. demonstrated that $\mathrm{CgA}$ induces calcium-dependent secretion of all Weibel-Palade body constituents, especially endothelin-1 [40]. Endothelin-1 has been implicated in vascular dysfunction by pro-inflammatory and pro-atherosclerotic effects [41] and has also been associated with CKD [42]. Dhaun et al. suggested that endothelin-1 could impair kidney function by acting one of its receptor called ETA, leading to the development of proteinuria through its effects on podocytes (alterations in actin skeleton, loss of nephrin) [43]. Moreover, endothelin-1 induces the release of pro-inflammatory and profibrotic cytokines via the 
activation of mesangial cells, and also induces cell proliferation and the production of matrix the macrophages infiltration in glomerulus. Yepuri et al. also provided other mechanisms leading to endothelial dysfunction such as impaired endothelial lysosomal acidification associated to impaired proteostasis [31]. Furthermore, nephrotoxicity of PPIs could be due to defects of lysosomal acidification and proteostasis, to hypomagnesemia or both, causing oxidative stress and leading to renal endothelial cell dysfunctions [44].

Concerning neurological defects, observational data are now supported by fundamental biological studies. First, PPIs such as omeprazole have been shown to cross the blood-brain barrier [45]. Badiola et al. demonstrated using in vitro and in vivo models that lansoprazole can increase amyloid- $\beta$ peptides, which is one of the major pathological hallmarks in Alzheimer disease [46]. Moreover, Fallahzadeh et al. hypothesized that PPIs could inhibit the V-ATPases on microglial lysosomes and lead to a basification of lysosomes, hampering degradation of amyloid- $\beta$ peptides [47]. Another factor increasing dementia in patients chronically treated by PPIs might be a vitamin B12 deficiency. Several studies described a decrease of vitamin B12 linked to prolonged use of PPIs, especially in elderly individuals [4849]. Indeed, reduced levels of vitamin B12 have been associated with cognitive impairment ([50-51]. A decrease of vitamin B12 enhances hyperhomocysteinemia, described to increase ADMA, which increases cardiovascular diseases that may cause cognitive decline, leading to Alzheimer disease [52]. Thus, cardiovascular impairment potentially induced by PPIs might also be considered as an important pathophysiological factor of dementia.

Finally, Marlicz et al. suggested the influence of PPIs on the gut microbiota as an alternative to explain an increased risk of chronic diseases linked to these molecules [53]. PPIs could affect the gut-vascular permeability leading to bacterial endotoxemia, described to strongly increase the risk of cardiovascular disease [54]. Moreover, composition of intestinal 
microbiota has been recently proposed as a key factor leading to aging-associated alterations [55], and could have a role in a cognitive decline by the so called 'gut-brain interactions' [56].

To date, biological effects were mostly evaluated in vitro. Several questions regarding these studies need to be answered such as the relevancy of doses used in vitro compared to therapeutic dose range used in patients partly because lower protein concentrations in culture medium than in plasma [57]. Similarly, drug penetration in cells could be very different in vitro compared to in vivo conditions due to the use of the vehicle (dimethyl sulphoxide, DMSO) increasing cell membrane permeability. Future studies need to understand all the underlying mechanisms involved in adverse effects of PPIs by following biological markers such as chromogranin A, endothelin-1, magnesium, B12 vitamin or DDAH and ADMA.

\section{Conclusion}

Even though in vivo studies are still required to understand and clarify the underlying mechanisms of such effects, the available fundamental and clinical data regarding drug safety should be considered. Actions should be undertaken particularly because these drug safety issues meet a body of evidence around the misuse and overprescribing of PPIs worldwide. As written by Lanas, even if the most of these adverse events have been mainly detected in observational studies, these potential adverse events should not be dismissed [2]. The magnitude of the use of these compounds, the high level of inappropriate use prescription worldwide, together with their potential association with serious adverse events, although low in frequency, may represent vast numbers of patients in absolute terms.

From now, these preliminary data should impose a very cautious attitude in the prescription of PPIs, especially in elderly individual and/or in the context of chronic use, even though the mechanisms involved in reported safety issues still have to be clarified. Awareness should be 
raised among prescribers both in hospital and primary care settings. Patients with PPIs prescription, especially those who are on long term therapy, should be regularly reviewed by their general practitioner. All patients admitted at hospital with a PPI prescription should also be reviewed for reassessment of the real need of maintaining their treatment. These educational initiatives should be implemented by regulatory authorities in order to limit inappropriate prescribing of PPI and keep these therapies well-used. Such initiatives should also be supported by warnings from regulatory authorities, especially given the recent safety concern raised about long-term use of PPI. 
Figure 1 : Plausible biological mechanisms leading to vascular events, nephrotoxycity and dementia 


\section{References}

[1] Kantor ED, Rehm CD, Haas JS, Chan AT, Giovannucci EL. Trends in Prescription Drug Use Among Adults in the United States From 1999-2012. JAMA. 2015 Nov 3;314(17):181831.

[2] Lanas A. We are using too many PPIs, and we need to stop: a European perspective. Am J Gastroenterol 2016;111:1085-6.

[3] ANSM. Vente des Médicaments en France : le rapport d'analyse de l'année 2013 http://ansm.sante.fr/S-informer/Presse-Communiques-Points-presse/Ventes-de-medicamentsen-France-le-rapport-d-analyse-de-1-annee-2013-Communique

[4] Pottegård A, Broe A, Hallas J, de Muckadell OB, Lassen AT, Lødrup AB. Use of protonpump inhibitors among adults: a Danish nationwide drug utilization study. Therap Adv Gastroenterol. 2016 Sep;9(5):671-8

[5] Hollingworth S, Duncan EL, Martin JH. Marked increase in proton pump inhibitors use in Australia. Pharmacoepidemiol Drug Saf. 2010 Oct;19(10):1019-24

[6] Sheen E, Triadafilopoulos G. Adverse effects of long-term proton pump inhibitor therapy. Dig Dis Sci. 2011 Apr;56(4):931-50

[7] Sheikh I, Waghray A, Waghray N, Dong C, Wolfe MM. Consumer use of over-thecounter proton pump inhibitors in patients with gastroesophageal reflux disease. Am J Gastroenterol. 2014 Jun;109(6):789-94

[8] Savarino V, Dulbecco P, de Bortoli N, Ottonello A, Savarino E. The appropriate use of proton pump inhibitors (PPIs): Need for a reappraisal. Eur J Intern Med. 2017 Jan;37:19-24

[9] Thorel J, McCambridge C, Piau A, Secher M, Magre É, Montastruc JL, Bagheri H. Proton pump inhibitors: Real indication or trivialized prescription? Therapie. 2016 Dec;71(6):589593

[10] Vaezi MF, Yang YX, Howden CW. Complications of Proton Pump Inhibitor Therapy. Gastroenterology. 2017 Jul;153(1):35-48

[11] Gomm W, von Holt K, Thomé F, Broich K, Maier W, Fink A, Doblhammer G, Haenisch B. Association of Proton Pump Inhibitors With Risk of Dementia: A Pharmacoepidemiological Claims Data Analysis. JAMA Neurol. 2016 Apr;73(4):410-6

[12] Tai SY, Chien CY, Wu DC, Lin KD, Ho BL, Chang YH, Chang YP. Risk of dementia from proton pump inhibitor use in Asian population: A nationwide cohort study in Taiwan. PLoS One. 2017 Feb 15;12(2):e0171006.

[13] Arora P, Gupta A, Golzy M, Patel N, Carter RL, Jalal K, Lohr JW. Proton pump inhibitors are associated with increased risk of development of chronic kidney disease. BMC Nephrol. 2016 Aug 3;17(1):112.

[14] Lazarus B, Chen Y, Wilson FP, Sang Y, Chang AR, Coresh J, Grams ME. Proton Pump Inhibitor Use and the Risk of Chronic Kidney Disease. JAMA Intern Med. 2016 Feb;176(2):238-46

[15] Shah NH, LePendu P, Bauer-Mehren A, Ghebremariam YT, Iyer SV, Marcus J, Nead KT, Cooke JP, Leeper NJ. Proton Pump Inhibitor Usage and the Risk of Myocardial Infarction in the General Population. PLoS One. 2015 Jun 10;10(6):e0124653. doi: 10.1371 [16] Wang YF, Chen YT, Luo JC, Chen TJ, Wu JC, Wang SJ. Proton-Pump Inhibitor Use and the Risk of First-Time Ischemic Stroke in the General Population: A Nationwide PopulationBased Study. Am J Gastroenterol. 2017 Apr 11.

[17] Haenisch B, von Holt K, Wiese B, Prokein J, Lange C, Ernst A, Brettschneider C, König HH, Werle J, Weyerer S, Luppa M, Riedel-Heller SG, Fuchs A, Pentzek M, Weeg D, Bickel 
H, Broich K, Jessen F, Maier W, Scherer M. Risk of dementia in elderly patients with the use of proton pump inhibitors. Eur Arch Psychiatry Clin Neurosci. 2015 Aug;265(5):419-28.

[18] Akter S, Hassan MR, Shahriar M, Akter N, Abbas MG, Bhuiyan MA. Cognitive impact after short-term exposure to different proton pump inhibitors: assessment using CANTAB software. Alzheimers Res Ther. 2015 Dec 27;7:79.

[19] Nevado-Holgado AJ, Kim CH, Winchester L, Gallacher J, Lovestone S. Commonly prescribed drugs associate with cognitive function: a cross-sectional study in UK Biobank. BMJ Open. 2016 Nov 30;6(11):e012177.

[20] Cassé-Perrot C, Lanteaume L, Deguil J, Bordet R, Auffret A, Otten L, Blin O, BartrésFaz D, Micallef J. Neurobehavioral and Cognitive Changes Induced by Sleep Deprivation in Healthy Volunteers. CNS Neurol Disord Drug Targets. 2016;15(7):777-801

[21] Xie Y, Bowe B, Li T, Xian H, Balasubramanian S, Al-Aly Z. Proton Pump Inhibitors and Risk of Incident CKD and Progression to ESRD. J Am Soc Nephrol. 2016 Oct;27(10):31533163.

[22] Xie Y, Bowe B, Li T, Xian H, Yan Y, Al-Aly Z. Long-term kidney outcomes among users of proton pump inhibitors without intervening acute kidney injury. KidneyInt. 2017 Jun;91(6):1482-1494

[23] Klatte DCF, Gasparini A, Xu H, de Deco P, Trevisan M, Johansson ALV, Wettermark B, Ärnlöv J, Janmaat CJ, Lindholm B, Dekker FW, Coresh J, Grams ME, Carrero JJ. Association Between Proton Pump Inhibitor Use and Risk of Progression of Chronic Kidney Disease. Gastroenterology. 2017 Jun 2. pii: S0016-5085(17)35688-3.

[24] Ho PM, Maddox TM, Wang L, Fihn SD, Jesse RL, Peterson ED, Rumsfeld JS. Risk of adverse outcomes associated with concomitant use of clopidogrel and proton pump inhibitors following acute coronary syndrome. JAMA. 2009 Mar 4;301(9):937-44

[25] Charlot M, Grove EL, Hansen PR, Olesen JB, Ahlehoff O, Selmer C, Lindhardsen J, Madsen JK, Køber L, Torp-Pedersen C, Gislason GH. Proton pump inhibitor use and risk of adverse cardiovascular events in aspirin treated patients with first time myocardial infarction: nationwide propensity score matched study. BMJ. 2011 May 11;342:d2690.

[26] Charlot M, Ahlehoff O, Norgaard ML, Jørgensen CH, Sørensen R, Abildstrøm SZ, Hansen PR, Madsen JK, Køber L, Torp-Pedersen C, Gislason G. Proton-pump inhibitors are associated with increased cardiovascular risk independent of clopidogrel use: a nationwide cohort study. Ann Intern Med. 2010 Sep 21;153(6):378-86.

[27] O'Donoghue ML, Braunwald E, Antman EM, Murphy SA, Bates ER, Rozenman Y, Michelson AD, Hautvast RW, Ver Lee PN, Close SL, Shen L, Mega JL, Sabatine MS, Wiviott SD. Pharmacodynamic effect and clinical efficacy of clopidogrel and prasugrel with or without a proton-pump inhibitor: an analysis of two randomised trials. Lancet. 2009 Sep 19;374(9694):989-97.

[28] Pello Lázaro AM, Cristóbal C, Franco-Peláez JA, Tarín N, Aceña Á, Carda R, Huelmos A, Martín-Mariscal ML, Fuentes-Antras J, Martínez-Millá J, Alonso J, Lorenzo Ó, Egido J, López-Bescós L, Tuñón J. Use of Proton-Pump Inhibitors Predicts Heart Failure and Death in Patients with Coronary Artery Disease. PLoS One. 2017 Jan 19;12(1):e0169826.

[29] Juurlink DN, Gomes T, Paterson JM, Hellings C, Mamdani MM. Trends in the coprescription of proton pump inhibitors with clopidogrel: an ecological analysis. CMAJ Open. 2015 Nov 26;3(4):E428-31.

[30] Shih CJ, Chen YT, Ou SM, Li SY, Chen TJ, Wang SJ. Proton pump inhibitor use represents an independent risk factor for myocardial infarction. Int J Cardiol. 2014 Nov 15;177(1):292-7.

[31] Yepuri G, Sukhovershin R, Nazari-Shafti TZ, Petrascheck M, Ghebre YT, Cooke JP. Proton Pump Inhibitors Accelerate Endothelial Senescence. Circ Res. 2016 Jun 10;118(12):e36-42. 
[32] Costarelli L, Giacconi R, Malavolta M, Basso A, Piacenza F, Provinciali M, Maggio senescent human coronary artery endothelial cells (HCAECs) by Omeprazole and Lansoprazole treatment. Biogerontology. 2017 Apr;18(2):217-236

[33] Brunner H, Cockcroft JR, Deanfield J, et al. Endothelial function and dysfunction. Part II: Association with cardiovascular risk factors and diseases. A statement by the Working Group on Endothelins and Endothelial Factors of the European Society of Hypertension. J Hypertens 2005;23:233-46

[34] Ghebremariam YT, LePendu P, Lee JC, Erlanson DA, Slaviero A, Shah NH, Leiper J, Cooke JP. Unexpected effect of proton pump inhibitors: elevation of the cardiovascular risk factor asymmetric dimethylarginine Circulation. 2013 Aug 20;128(8):845-53

[35] EMA. 21 July 2016 EMA/PRAC/452657/2016 Corr1 - Pharmacovigilance Risk Assessment Committee

(PRAC) http://www.ema.europa.eu/docs/en_GB/document_library/PRAC_recommendation_on_signal /2016/07/WC500210321.pdf

[36] Mosli HH, Dennis A, Kocha W, Asher LJ, Van Uum SH. Effect of short-term proton pump inhibitor treatment and its discontinuation on chromogranin A in healthy subjects. J Clin Endocrinol Metab. 2012 Sep;97(9):E1731-5.

[37] Angelone T, Mazza R, Cerra MC. Chromogranin-A: a multifaceted cardiovascular role in health and disease. Curr Med Chem. 2012;19(24):4042-50

[38] Tota B, Angelone T, Cerra MC. The surging role of Chromogranin A in cardiovascular homeostasis. Front Chem. 2014 Aug 14;2:64.

[39] Theurl M, Schgoer W, Albrecht K, Jeschke J, Egger M, Beer AG, Vasiljevic D, Rong S, Wolf AM, Bahlmann FH, Patsch JR, Wolf D, Schratzberger P, Mahata SK, Kirchmair R. The neuropeptide catestatin acts as a novel angiogenic cytokine via a basic fibroblast growth factor-dependent mechanism. Circ Res. 2010 Nov 26;107(11):1326-35

[40] Chen Y, Mahata M, Rao F, Khandrika S, Courel M, Fung MM, Zhang K, Stridsberg M, Ziegler MG, Hamilton BA, Lipkowitz MS, Taupenot L, Nievergelt C, Mahata SK, O'Connor DT. Chromogranin A regulates renal function by triggering Weibel-Palade body exocytosis. J Am Soc Nephrol. 2009 Jul;20(7):1623-32.

[41] Böhm The importance of endothelin-1 for vascular dysfunction in cardiovascular disease Cardiovascular Research, 2007, 76, 8-18

[42] Kohan DE. Endothelin, hypertension and chronic kidney disease: new insights. Curr Opin Nephrol Hypertens. 2010 Mar;19(2):134-9.

[43] Dhaun N, Webb DJ, Kluth DC. Endothelin-1 and the kidney--beyond BP. Br J Pharmacol. 2012 Oct;167(4):720-31

[44] Arif F. Nephrotoxic potential of proton pump inhibitors. Eur J Intern Med. 2017 Apr 1. pii: S0953-6205(17)30125-

[45] Cheng FC, Ho YF, Hung LC, Chen CF, Tsai TH. Determination and pharmacokinetic profile of omeprazole in rat blood, brain and bile by microdialysis and high-performance liquid chromatography. J Chromatogr A. 2002 Mar 8;949(1-2):35-42.

[46] Badiola N, Alcalde V, Pujol A, Münter LM, Multhaup G, Lleó A, Coma M, Soler-López M, Aloy P. The proton-pump inhibitor lansoprazole enhances amyloid beta production. PLoS One. 2013;8(3):e58837.

[47] Fallahzadeh MK, Borhani Haghighi A, Namazi MR. Proton pump inhibitors: predisposers to Alzheimer disease? J Clin Pharm Ther. 2010 Apr;35(2):125-6.

[48] Dharmarajan TS, Norkus EP. Does long-term PPI use result in vitamin B12 deficiency in elderly individuals? Nat Clin Pract Gastroenterol Hepatol. 2008 Nov;5(11):604-5.

[49] Lam JR, Schneider JL, Zhao W, Corley DA. Proton pump inhibitor and histamine 2 receptor antagonist use and vitamin B12 deficiency. JAMA. 2013 Dec 11;310(22):2435-42. 
[50] Eastley R, Wilcock GK, Bucks RS. Vitamin B12 deficiency in dementia and cognitive impairment: the effects of treatment on neuropsychological function. Int J Geriatr Psychiatry. 2000 Mar; 15(3):226-33.

[51] Kim G, Kim H, Kim KN, Son JI, Kim SY, Tamura T, Chang N. Relationship of cognitive function with B vitamin status, homocysteine, and tissue factor pathway inhibitor in cognitively impaired elderly: a cross-sectional survey. J Alzheimers Dis. 2013;33(3):853-62.

[52] Daulatzai MA. Cerebral Hypoperfusion and Glucose Hypometabolism: Key Pathophysiological Modulators Promote Neurodegeneration, Cognitive Impairment, and Alzheimer's Disease Journal of Neuroscience Research 2017, 95:943-972

[53] Marlicz W, Koulaouzidis A, Loniewski I, Koulaouzidis G. Letter by Marlicz et al Regarding Article, "Proton Pump Inhibitors Accelerate Endothelial Senescence". Circ Res. 2016 Jul 8;119(2):e31-2

[54] Wiedermann CJ, Kiechl S, Dunzendorfer S, Schratzberger P, Egger G, Oberhollenzer F, Willeit J. Association of endotoxemia with carotid atherosclerosis and cardiovascular disease: prospective results from the Bruneck Study. J Am Coll Cardiol. 1999 Dec;34(7):1975-81

[55] Vaiserman AM, Koliada AK, Marotta F. Gut microbiota: A player in aging and a target for anti-aging intervention. Ageing Res Rev. 2017 May;35:36-45.

[56] Caracciolo B, Xu W, Collins S, Fratiglioni L. Cognitive decline, dietary factors and gutbrain interactions. Mech Ageing Dev. 2014 Mar-Apr;136-137:59-69.

[57] Perrin S, Cremer J, Faucher O, Reynes J, Dellamonica P, Micallef J, Solas C, Lacarelle B, Stretti C, Kaspi E, Robaglia-Schlupp A, Nicolino-Brunet C, Tamalet C, Lévy N, PoizotMartin I, Cau P, Roll P. HIV protease inhibitors do not cause the accumulation of prelamin A in PBMCs from patients receiving first line therapy: the ANRS EP45 "aging" study. PLoS One. 2012;7(12):e53035. 
Table 1 Published positive pharmacoepidemiological studies assessing a potential association between IPP and adverse events (dementia, chronic kidney disease and vascular events such as stroke or myocardial infarction)

\begin{tabular}{|c|c|c|c|c|c|c|}
\hline $\begin{array}{c}\text { Potential adverse } \\
\text { effects }\end{array}$ & $\begin{array}{l}\text { Authors } \\
\text { (date) } \\
\text { Country }\end{array}$ & Journal & Design & $\begin{array}{l}\text { Study } \\
\text { period }\end{array}$ & $\begin{array}{l}\text { Principal } \\
\text { Endpoints }\end{array}$ & Main results \\
\hline Dementia & $\begin{array}{l}\text { Haenisch et al } \\
\text { (2015) } \\
\text { Germany }\end{array}$ & $\begin{array}{l}\text { Eur Arch Psychiatry } \\
\text { Clin Neurosci }\end{array}$ & $\begin{array}{l}\text { Longitudinal multicenter } \\
\text { cohort study in the } \\
\text { German Study on Aging, } \\
\text { Cognition and Dementia } \\
\text { in primary care cphort } \\
\text { (AgeCoDe) }\end{array}$ & 18 month & $\begin{array}{c}\text { Diagnosis of } \\
\text { dementia or } \\
\text { Alzheimer's } \\
\text { disease } \\
\text { (Structured } \\
\text { Interview for } \\
\text { Diagnosis of } \\
\text { Dementia of } \\
\text { Alzheimer type } \\
\text { - SIDAM; DSM } \\
\text { IV and ICD-10) }\end{array}$ & $\begin{array}{c}\mathrm{HRa}, 1.38,95 \% \mathrm{Cl}, 1.04-1.83 \text { (Dementia) } \\
\mathrm{HRa}, 1.44,95 \% \mathrm{Cl}, 1.01-2.06 \text { (Alzheimer's disease) }\end{array}$ \\
\hline Dementia & $\begin{array}{l}\text { Gomm et al } \\
\text { (2016) } \\
\text { Germany }\end{array}$ & JAMA neurology & $\begin{array}{c}\text { Prospective cohort } \\
\text { study in the Allgemeine } \\
\text { Ortskrakerkassen } \\
\text { database (largest } \\
\text { German statutory health } \\
\text { insurer) }\end{array}$ & $2004-2011$ & $\begin{array}{l}\text { Diagnosis of } \\
\text { incident } \\
\text { dementia (ICD- } \\
\text { 10) }\end{array}$ & $\mathrm{HRa}, 1.44 ; 95 \% \mathrm{Cl}, 1.36-1.52$ \\
\hline Dementia & $\begin{array}{l}\text { Tai et al } \\
\text { (2017) } \\
\text { Taiwan }\end{array}$ & Plos one & $\begin{array}{l}\text { Retrospective study in } \\
\text { the Taiwan's national } \\
\text { Health Insurance } \\
\text { research Database }\end{array}$ & $2000-2003$ & $\begin{array}{l}\text { hospitalization } \\
\text { for dementia, } \\
\text { and a diagnosis } \\
\text { made by a } \\
\text { neurologist or } \\
\text { psychiatrist } \\
\text { (ICD-9) }\end{array}$ & $\begin{array}{c}\text { HRa, } 1.22 ; 95 \% \mathrm{Cl} 1.05 \pm 1.42 \\
\text { HRa, } 1.19 ; 95 \% \mathrm{Cl} 0.95 \pm 1.48 \text { (cumulative PPI use) }\end{array}$ \\
\hline Chronic Kidney & Xie et al & J Am Soc Nephrol & $\begin{array}{l}\text { Retrospective study in } \\
\text { the US Department of }\end{array}$ & $2006-2008$ & $\begin{array}{l}\text { Incident CKD : } \\
\text { two eGFRs } 60\end{array}$ & HRa, 1.28; 95\%Cl, 1.23-1.34 (CKD) \\
\hline
\end{tabular}




\begin{tabular}{|c|c|c|c|c|c|c|}
\hline disease & $\begin{array}{l}\text { (2016) } \\
\text { USA }\end{array}$ & & $\begin{array}{l}\text { veterans affairs cohort } \\
\text { using a propensity } \\
\text { matched score }\end{array}$ & & $\begin{array}{c}\mathrm{ml} / \mathrm{min} \text { per } 1.73 \\
\mathrm{~m} 2 \text { least } 90 \\
\text { days apart } \\
\text { Kidney disease } \\
\text { progression: } \\
\text { eGFR decline } \\
\text { over } 30 \% \\
\text { ESRD } \\
\text { (including } \\
\text { participants } \\
\text { with AKI) }\end{array}$ & $\begin{array}{c}\mathrm{HRa}, 1.32 ; 95 \% \mathrm{Cl}, 1.23-1.34 \text { (>30\% decline in eGFR) } \\
\mathrm{HRa}, 1.96 ; 95 \% \mathrm{Cl}, 1.21 \text { to } 3.18 \text { (ESRD) } \\
\begin{array}{c}\text { Graded association between duration of PPI exposure and risk } \\
\text { of renal outcomes }\end{array}\end{array}$ \\
\hline $\begin{array}{l}\text { Chronic Kidney } \\
\text { disease }\end{array}$ & $\begin{array}{l}\text { Lazarasus et } \\
\text { al } \\
\qquad \begin{array}{c}(2016) \\
\text { USA }\end{array}\end{array}$ & $\begin{array}{l}\text { JAMA internal } \\
\text { medicine }\end{array}$ & $\begin{array}{l}\text { Atherosclerosis Risk in } \\
\text { Communities (ARIC) } \\
\text { cohort \& Geisinger } \\
\text { Health System (GHS) } \\
\text { cohort linked to the } \\
\text { United States Renal } \\
\text { Data Systemregistry } \\
\text { Case control study }\end{array}$ & $\begin{array}{l}1996-2011 \\
1997-2014\end{array}$ & $\begin{array}{c}\text { CKD } \\
\text { AKI } \\
\text { (ICD-9-CM or } \\
\text { ICD-10-CM) }\end{array}$ & $\begin{array}{c}\text { CKD } \\
\text { ARIC cochort: } \\
\text { HRa, 1.50; } 95 \% \mathrm{Cl}, 1.14-1.96 \\
\text { GSH cohort: } \\
\text { HRa, 1.17; } 95 \% \mathrm{Cl}, 1.12-1.23 \\
\text { AKI } \\
\text { ARIC cochort: } \\
\text { HRa, 1.64; } 95 \% \mathrm{Cl}, 1.22-2.21 \\
\text { GSH cohort: } \\
\text { HRa, 1.31; } 95 \% \mathrm{Cl}, 1.22-1.42\end{array}$ \\
\hline $\begin{array}{l}\text { Chronic Kidney } \\
\text { disease }\end{array}$ & $\begin{array}{l}\text { Arora et al } \\
\text { (2016) } \\
\text { USA }\end{array}$ & BMC Nephrology & $\begin{array}{c}\text { Retrospective study in } \\
\text { the Veterans Affairs } \\
\text { Health Care Upstate } \\
\text { New York (VISN2) } \\
\text { network } \\
\text { Case control study }\end{array}$ & $2001-2008$ & $\begin{array}{l}\text { CKD } \\
\text { Death } \\
\text { (ICD) }\end{array}$ & $\begin{array}{c}\text { OR, 1.10; } 95 \text { \% Cl 1.05-1.16 (CKD) } \\
\text { OR, 1.76; } 95 \% \text { Cl 1.67-1.84 (mortality) }\end{array}$ \\
\hline $\begin{array}{l}\text { Chronic Kidney } \\
\text { disease }\end{array}$ & $\begin{array}{l}\text { Xie et al } \\
\text { (2017) } \\
\text { USA }\end{array}$ & Kidney International & $\begin{array}{l}\text { Retrospective study in } \\
\text { the US Department of } \\
\text { veterans affairs cohort } \\
\text { using a propensity } \\
\text { matched score }\end{array}$ & $2006-2008$ & $\begin{array}{l}\text { Incident CKD: } \\
\text { two eGFRs } 60 \\
\text { ml/min per } 1.73 \\
\text { m2 least } 90 \\
\text { days apart } \\
\text { eGFR decline }\end{array}$ & $\begin{array}{c}\text { HRa, 1.19; } 95 \% \mathrm{Cl}, 1.15-1.24 \text { ((eGFR) under } 60 \mathrm{ml} / \mathrm{min} / 1.73 \mathrm{~m} 2 \\
\mathrm{HR}, 1.26 ; 95 \% \mathrm{Cl}, 1.20-1.33 \text { (CKD) } \\
\mathrm{HRa}, 1.22 ; 95 \% \mathrm{Cl}, 1.16-1.28 \text { ) (eGFR decline over } 30 \% \text { ) }\end{array}$ \\
\hline
\end{tabular}




\begin{tabular}{|c|c|c|c|c|c|c|}
\hline & & & & & $\begin{array}{l}\text { over } 30 \% \\
\text { ESRD or eGFR } \\
\text { decline over } \\
50 \% \\
\text { (excluding } \\
\text { participants } \\
\text { with AKI) }\end{array}$ & $\mathrm{HRa}, 1.30 ; 95 \% \mathrm{Cl}, 1.15-1.48$ (ESRD or eGFR decline over 50\%) \\
\hline $\begin{array}{l}\text { Chronic Kidney } \\
\text { disease }\end{array}$ & $\begin{array}{l}\text { Klatte et al } \\
\text { (2017) } \\
\text { Sweden }\end{array}$ & Gastroenterology & $\begin{array}{l}\text { Retrospective study in } \\
\text { the Stockholm } \\
\text { creatinine } \\
\text { measurements database }\end{array}$ & 2007-2010. & $\begin{array}{l}\text { Progression } \\
\text { CKD: doubling } \\
\text { of creatinine or } \\
\text { decrease in } \\
\text { eGFR }>30 \% \\
\text { ESRD } \\
\text { AKI }\end{array}$ & $\begin{array}{c}\text { HRa, 1.26; } 95 \% \mathrm{Cl}, 1.05-1.51 \text { (doubling creatinine) } \\
\text { HRa, 1.26; } 95 \% \mathrm{Cl}, 1.16-1.36 \text { (decrease in eGFR > 30\%) } \\
\mathrm{HRa}, 2.40 ; 95 \% \mathrm{Cl}, 0.76-7.58 \text { (ESRD) } \\
\mathrm{HRa}, 1.30 ; 95 \% \mathrm{Cl}, 1.00-1.69 \text { (AKI) } \\
\text { Graded association between cumulative exposure to PPIs and } \\
\text { risk of CKD progression }\end{array}$ \\
\hline $\begin{array}{l}\text { Cardiovascular } \\
\text { events } \\
\text { (Myocardial } \\
\text { infarctus) }\end{array}$ & $\begin{array}{l}\text { Juurlink et al } \\
\qquad \begin{array}{c}\text { (2013) } \\
\text { Ontario- } \\
\text { Canada }\end{array}\end{array}$ & Plos One & $\begin{array}{l}\text { Ontario Drug Benefit } \\
\text { Claims Database \& } \\
\text { Canadian Institute for } \\
\text { Health Information's } \\
\text { Discharge Abstract } \\
\text { Database (CIHI-DAD) \& } \\
\text { Health Insurance Plan } \\
\text { Database } \\
\text { Self-matched case series } \\
\text { method in }\end{array}$ & $1996-2008$ & $\begin{array}{l}\text { hospitalization } \\
\text { for acute } \\
\text { myocardial } \\
\text { infarction and } \\
\text { hospitalization } \\
\text { for heart failure } \\
\text { ((ICD-9-CM or } \\
\text { ICD-10-CM) }\end{array}$ & $\begin{array}{l}\text { OR } 1.8 ; 95 \% \mathrm{Cl} 1.7-1.9 \text { (acute myocardial infarction) } \\
\qquad \text { OR } 1.8 ; 95 \% \mathrm{Cl} 1.7-1.9 \text { (heart failure) }\end{array}$ \\
\hline $\begin{array}{l}\text { Cardiovascular } \\
\text { events } \\
\text { (Myocardial } \\
\text { infarctus) }\end{array}$ & $\begin{array}{l}\text { Shih et al } \\
\text { (2014) } \\
\text { Taiwan }\end{array}$ & Int J Cardiology & $\begin{array}{l}\text { Longitudinal Health } \\
\text { Insurance Database } \\
\text { (LHID) } \\
\text { propensity score - } \\
\text { matching analyses } \\
\text { \& case-crossover study }\end{array}$ & 2000-2009 & $\begin{array}{l}\text { hospitalization } \\
\text { for myocardial } \\
\text { infarction (ICD9- } \\
\text { CM) }\end{array}$ & $\begin{array}{c}\text { Propensity score -matching analyses } \\
\text { HRa, } 1.581 ; 95 \% \mathrm{Cl}, 1.11-2.25 \\
\text { Case-crossover study } \\
\text { OR, } 4.61 ; 95 \% \mathrm{Cl}, 1.76-12.07 \text {, 7-day window } \\
\text { OR, } 3.47 ; 95 \% \mathrm{Cl}, 1.76-6.83,14 \text {-day window }\end{array}$ \\
\hline
\end{tabular}


hospitalization with a primary

diagnosis of

ischemic stroke (ICD-9-CM)
HRa, 1.36; 95\% Cl, 1.14-1.62 (propensity score)

HRa, 1.77; 95\% Cl1.45-2.18 within 30 days (nested case control design) 
